\title{
Coming out of the dark: Content analysis of articles pertaining to gay, lesbian, and bisexual issues in couple and family therapy journals
}

\author{
Erica E. Hartwell \\ Fairfield University, ehartwell@fairfield.edu \\ Julianne M. Serovich \\ Erika L. Grafsky \\ Zachary Y. Kerr
}

Follow this and additional works at: https://digitalcommons.fairfield.edu/education-facultypubs This is an archived pre-print of an article subsequently published in Journal of Marital and Family Therapy - Copyright 2012 Wiley.

\section{Repository Citation}

Hartwell, Erica E.; Serovich, Julianne M.; Grafsky, Erika L.; and Kerr, Zachary Y., "Coming out of the dark: Content analysis of articles pertaining to gay, lesbian, and bisexual issues in couple and family therapy journals" (2012). GSEAP Faculty Publications. 89.

https://digitalcommons.fairfield.edu/education-facultypubs/89

\section{Published Citation}

Hartwell, E. E., Serovich, J. M., Grafsky, E. L., \& Kerr, Z. Y. (2012). Coming out of the dark: Content analysis of articles pertaining to gay, lesbian, and bisexual issues in couple and family therapy journals. Journal of Marital and Family Therapy, 38, 227-243. DOI: 10.1111/j.1752-0606.2011.00274.x

This item has been accepted for inclusion in DigitalCommons@Fairfield by an authorized administrator of DigitalCommons@Fairfield. It is brought to you by DigitalCommons@Fairfield with permission from the rightsholder(s) and is protected by copyright and/or related rights. You are free to use this item in any way that is permitted by the copyright and related rights legislation that applies to your use. For other uses, you need to obtain permission from the rights-holder(s) directly, unless additional rights are indicated by a Creative Commons license in the record and/or on the work itself. For more information, please contact digitalcommons@fairfield.edu. 
Coming Out of the Dark: Content Analysis of Articles Pertaining to Gay, Lesbian, and Bisexual Issues in Couple and Family Therapy Journals

Erica E. Hartwell, Julianne M. Serovich, Erika L. Grafsky \& Zachary Y. Kerr

Erica E. Hartwell is a Couple and Family Therapy doctoral student, Julianne M. Serovich is Professor and Chair, and Erika L. Grafsky is a Couple and Family Therapy doctoral candidate in the Department of Human Development and Family Science at The Ohio State University. Zackary Kerr is an Epidemiology doctoral student at The University of North Carolina-Chapel Hill. Address correspondence to the first author, Department of Human Development and Family Science, 1787 Neil Avenue, Columbus, OH, 43210. Phone: (614) 292-5685; fax: (614) 292-4365. E-mail: ehartwell@ehe.osu.edu. 


\begin{abstract}
The present study seeks to extend previous research regarding literature related to gay, lesbian, and bisexual (GLB) issues published in couple and family therapy (CFT) related journals (Clark \& Serovich, 1997) by presenting the results from a content analysis of GLB studies in CFT related journals from 1996-2010. Results of the analysis revealed a $238.8 \%$ increase in total GLB content published since the original review. Articles pertaining to therapy with GLB clients continue to represent the largest area of publication. With one exception, all surveyed journals showed an increase in the percentage of GLB content since the first study. Emerging areas of research include studies related to supervision and training, GLB mental health and substance use, and sexual minority adolescents. Furthermore, a movement away from deficitbased perspectives could open a new lens on family life.
\end{abstract}

Keywords: Content Analysis; Sexual Minority, Couple and Family Therapy 


\section{Introduction}

In 1997 the Journal of Marital and Family Therapy published a content analysis on articles pertaining to gay, lesbian, and bisexual (GLB) issues published in couple and family therapy (CFT) related journals from 1975 through 1995 (Clark \& Serovich, 1997). The authors found that out of 13,217 articles published in 17 carefully selected journals, less than $1 \%$ ( $n=$ 77) focused on GLB issues. Of those articles published, most focused on dynamics of GLB relationships (29\%) or the "treatment" or attempts to "change" or "cure" homosexuality (17\%). Most of the literature was theoretical or clinical in nature with very few being empirical (qualitative or quantitative). The authors concluded that GLB populations were not being adequately studied by couple and family therapists and provided three compelling reasons for this outcome. First, authors seeking to publish work on GLB issues may be seeking outlets other than those typically consumed by CFT's. Second, heterosexist bias or fear may discourage researchers from developing research agendas that include this diverse population. Finally, researchers may be misled into thinking there is more academic knowledge available than exists.

Inadequate understanding of the lives of GLB persons may have dangerous effects on both clinicians and the clients that they seek to serve (Long, 1996). Long and Serovich (2003) argue that despite the call for integration of sexual orientation into the CFT curriculum, the subject is largely marginalized and poorly addressed in most programs. Many authors agree that family therapists are ill-prepared to work with sexual minority clients (Clark \& Serovich, 1997; Laird \& Green, 1995; Long, 1996, 2000). Recently, Henke, Carlson, and McGeorge (2009) published a study surveying CFT's reported homophobia and clinical competency in working with GLB populations. They make the argument that without an understanding of heterosexism and internalized homophobia, CFT's are not equipped to work with GLB clients. Their study 
found that on average, participants reported being fairly confident in their abilities to work with GLB clients but reported being only somewhat aware of the mental health needs and experiences of those clients. These contradictory findings echoed the finding of Doherty and Simmons (1996), who found that about half of all CFT's did not feel competent in treating GLB clients. CFT's lack of competence seems troubling in light of one study that found that nearly threequarters of American Association for Marriage and Family Therapy (AAMFT) members report one-tenth of their practice consists of GLB clients (Green \& Bobele, 1994).

Since the Clark and Serovich paper (hereafter referred to as the "original study") was published, American culture has seen significant changes in relation to sexual minority individuals and these changes impact the field of CFT. For example, the Supreme Court has struck down the anti-sodomy law in Texas, affirming the rights of consenting adult partners (both heterosexual and homosexual) across the country to privacy regarding their sexual lives (Lawrence v. Texas, 2003). In the past decade, six states, including the District of Columbia, have legalized same-sex marriage, five states have introduced same-sex partnerships with benefits equivalent to marriage, and four other states have introduced various forms of nonequivalent partnerships for same-sex couples (Human Rights Campaign, 2010). In addition, currently, the United States Congress is taking steps toward ending the ban on openly lesbian and gay military service members. These changes impact the relationships and emotional well-being of GLB persons and could subsequently alter reasons for presenting in therapy.

AAMFT as an organization has also taken extraordinary measures in depathologizing homosexuality. In 2005, the AAMFT issued two statements of non-discrimination based on sexual orientation. In these statements the AAMFT endorsed same-sex couples' rights to "equal benefits, protection, and responsibility" (AAMFT, 2005a); reaffirmed its position of non- 
discrimination based on sexual orientation (AAMFT, 2005a); and encouraged same-sex couples to "engage with marriage and family therapists for relational development and problem solving within their cultural context" (AAMFT, 2005b). In addition, the AAMFT Board of Directors issued a statement on March 25, 2009 affirming that AAMFT as an organization does not consider homosexuality a disorder that requires treatment; therefore there is no basis for the use of reorientation therapies.

Unfortunately, while some strides have been made within the organization in recent years to promote ethical service for GLBT clients, the Commission on Accreditation for Marriage and Family Therapy Education (COAMFTE) has recently established vague standards (AAMFT, 2005c) for incorporating issues related to sexual orientation into accredited training programs for couple and family therapists. COAMFTE now recommends, but does not require, that programs follow educational guidelines which suggest providing comprehensive views of sexuality and specific training for working with clients of various sexual orientations. These changes suggest that there is still room for the organization and field as a whole to become more accepting and competent regarding the needs and issues faced by GLB clients and their families.

The purpose of this paper is to investigate if changes have occurred in regards to attention paid to GLB issues in the research literature. This study reports the results of a content analysis of GLB-related articles beginning where the original study left off (beginning of 1996) and continuing through 2009. The following research questions guided this investigation:

1. To what degree have the articles published in CFT journals since 1996 addressed gay, lesbian, bisexual issues? Has this changed since the previously reviewed period of 1975-1995? 
2. What is the nature of the literature being published in CFT related journals? Are there any emergent themes?

3. What types of articles are being published? What designs are used (i.e. quantitative, qualitative, clinical, etc)?

\section{Method}

The methodology employed in the original study was replicated in this investigation. That is, all articles published in journals deemed influential in the field of couple and family therapy published from 1996 through 2009 (see Table 1) were searched and reviewed to determine the presence of GLB content. Articles included in this study were full-length articles, brief reports and reflections. Introductions, comments, reviews, editorials, presidential addresses, interviews, and replies were excluded. Articles that contained GLB content but whose main focus seemed to be on larger diversity or multicultural issues were also excluded. Articles focused on transgender issues were not included in the original study and thus are not included in this analysis. Including them now could inflate results and hinder accurate assessment of change in publication trends over time. The discussion of this paper highlights issues related to the inclusion of articles related to transgender issues. Articles on HIV/AIDS that included sexual orientation as a major component were included.

The same journals were reviewed as in the original study with three exceptions. First, the Journal of Family Psychotherapy incorporated the Journal of Psychotherapy and the Family in 1990 so that all articles in this analysis are from the Journal of Family Psychotherapy. Second, two journals changed their name. Family Systems Medicine changed their name to Families, Systems, and Health and the Journal of Couples Therapy became the Journal of Couple and Relationship Therapy. The new journal titles are reported here. Finally, the Journal of Sex and 
Marital Therapy is an influential publication that was not included in the first study and so is included in this one. Thus, 17 journals (see Table 1) were included in the analysis.

Each article was reviewed and coded by at least two of the authors. The first coder recorded all relevant information about the article and the second coder verified it. If there were differences of opinion that could not be rectified, a third coder was consulted. Three separate sorts of the articles were conducted based on the original study. The categories for the first sort were based on Morin's (1977) original taxonomy and the second was based on his areas for future research. The third sort was conducted using relationally oriented categories previously established in the original study.

\section{Results}

To investigate to what degree current articles published in CFT journals address gay, lesbian, and bisexual issues, the proportions of GLB articles from 1996-2009 were calculated by journal (see Table 1). During the 14 years since the original study was conducted, there were 8,781 articles published in the 17 surveyed journals. Of those, $173(2 \%)$ focused on gay, lesbian, or bisexual issues (see Appendix for a complete list of articles). To determine whether the proportion of GLB content in CFT journals has changed, the current percentage (2\%) was compared to that found in the original study (.6\%). This change represents a $238.8 \%$ increase in total GLB content.

In terms of number of articles containing GLB content, the Journal of Consulting and Clinical Psychology published the most (21), followed by the Journal of Couple and Relationship Therapy (19) and the Journal of Marital and Family Therapy (17). However, in terms of percentages, the Journal of Couple and Relationship Therapy had the highest with 7.2\% of its total articles related to GLB content. The Journal of Feminist Family Therapy followed 
closely behind with $6.4 \%$. With one exception, all surveyed journals showed an increase in the percentage of GLB content since the first study. Behavior Therapy published no articles on GLB issues from 1996 through 2009.

Table 2 displays the distribution trends of the articles by year. These data suggest that there has been a rather stable rate of publication of 12.36 articles $(s d=3.65)$ per year. There were spikes in 2003, 2004 and 2008 when between 16 and 20 articles appeared each year. In 2004 this could be attributed to a special issue in the Journal of Couple and Relationship Therapy.

To investigate the nature of the literature being published in CFT journals, the authors conducted three different sorts of the articles. The first sort used Morin's (1977) original typology. Table 3 displays the results of this sort from the current study, the original study, Morin's study, and two other studies that examined the psychological literature. None of the articles in the current investigation were related to assessment, two addressed causes of homosexuality (1\%), 18 pertained to adjustment to homosexuality (10\%), 20 were concerned with attitudes about homosexuality (12\%), and 133 were categorized as special topics (77\%). The most notable change from the original study is a considerable increase in the number of articles labeled as special topics and the decrease of articles in all other categories.

The second sort was conducted using Morin's (1977) categories for future research (see Table 4). Similar to the 1997 article, $30 \%$ of the articles were classified as pertaining to the dynamics of gay and lesbian relationships $(n=52)$. This highlights the continued relational focus of the CFT field. The nine categories established by Morin were found to be insufficient in classifying current research as no appropriate label for 51 articles $(29.6 \%)$ was found. 
In the original study, the authors created a new set of categories that better represented the relational focus of the CFT field. According to this classification, the most common category was therapy with GLB clients, with 40 articles (23.1\%). Twenty-eight (16.2\%) articles were labeled as "other". Among those deemed "other," 11 were categorized as mental health issues/substance use, six as training/supervision of therapists, and five as pertaining to adolescents. Similar to the 1997 study, a considerable proportion of articles $(n=27,15.6 \%)$ were concerned with HIV/AIDS.

Regarding the type or design of the included studies, 76 articles (43.9\%) were identified as clinical or theoretical (Table 6). This category also included case studies, literature reviews, reflections, and historical pieces. Sixty-eight (39.3\%) were quantitative; 23 (13.3\%) were qualitative methods; and five (2.9\%) employed mixed methods. The representation of methodologies in this review were strikingly similar to that of the original study, suggesting that the type of research being conducted with or regarding GLB populations has not changed, although the specific phenomena being studied has evolved.

Only $32.4 \%(n=56)$ of the articles reviewed presented a theory as the foundation of the study. The most predominant theory cited was feminist theory $(n=10)$ and this included feminist family therapy theory as well as feminist theory applied with grounded or social constructionist theories. Other theories cited often included family systems theory $(n=6)$, narrative therapy theory $(n=5)$, social constructivist theory $(n=5)$, Bowen family systems theory $(n=4)$, cognitive-behavioral theory $(n=4)$, and ecological systems theory $(n=4)$.

\section{Discussion}

The results of this study are promising for the representation of diversity in the field of CFT, yet also suggest that this representation is severely lacking in scope and depth. Overall, the 
$238 \%$ increase in total GLB content published in scholarly journals related to the field of couple and family therapy since the original study is impressive. Obviously, research regarding GLB issues is increasing along with the concurrent ethical and policy related changes the field has made in the past decade. While the increase in number of publications is substantial and encouraging, perspective on the magnitude of this increase should be assessed.

Only $2 \%$ of the total articles in the journals surveyed contained GLB content. Given that nearly three-quarters of AAMFT members report one-tenth of their practice consists of GLB clients (Green \& Bobele, 1994), the amount of literature devoted to this population remains insufficient. If CFTs aim to increase their feelings of competency and decrease the impact of homophobia on their practice, more resources upon which they can draw when working with GLB clients need to be readily available. Also, it is in the best interest of the field of CFT for researchers and practitioners to stay informed regarding the rationale behind and impact of recent political and ethical changes and how those policies may impact individual clients.

Since the original study, the topics related to GLB issues being published in CFT journals have changed. The majority of the articles found to contain GLB content could not be categorized according to Morin's (1977) original typologies outside of the broad "special topics" category. This result is encouraging as it suggests that the field has moved beyond an interest in the causes, assessment of, and adjustment to homosexuality. This also reflects the larger scientific and societal literature base that accepts same-sex attraction as a normal and healthy part of sexuality. Researchers should broaden their understanding of GLB individuals through researching new areas of investigation such as the nature of bisexuality or the concept of sexual fluidity. 
Morin (1977) suggested nine areas for future research regarding GLB content. While the category of dynamics of gay and lesbian relationships remained salient, the other categories have lost their relevance when examined in the context of more recent GLB literature and do not accurately reflect the nature of the literature that is published in the field of couple and family therapy. However, the categories created by Clark and Serovich (1996) to reflect the relational nature of the CFT field were more salient in this investigation. One noticeable distinction between the present study and that of the original study was the smaller proportion of articles related to the treatment of homosexuality/attempts to change or cure. The dwindling number of articles could be attributed to the fact that Behavior Therapy, which published the majority of articles related to the treatment and attempts to change or cure homosexuality in the original study, did not publish any GLB-related articles in the current study. Moreover, the lack of articles may illustrate the declining popularity and acceptance of reparative treatments. Nevertheless, many behaviorally-based treatments that could benefit GLB clients, such as treatments for depression, eating disorders, and body image disorder, exist and should be investigated by behavioral researchers.

At the same time, the "other" category in the Clark and Serovich (1996) categorization highlights trends in the literature that are closely related to changes in the societal focus. Topics most frequently sorted into this grouping addressed mental health/substance use issues, supervision or training of therapists, and issues related to adolescence. The increase in literature being published in such areas informs clinicians of the presence of mental health issues and substance use issues in persons that identify as GLB and adolescents first encountering and exploring their same-sex attractions. Furthermore, literature published on the topics of 
supervision and training of therapists can assist supervisors and training programs in educating therapists to be culturally competent with GLB clients.

Previous literature has collected a number of important areas for which CFTs should be knowledgeable; however, societal changes have created the need to examine relatively newer areas of research that focus on factors that facilitate or deter GLB individuals' and couples' conceptualizations of family (i.e., adoption bans). For example, there is an emerging literature base on lesbian parenting reflecting the increased visability of this family form. Other family forms; however, are not receiving similar attention. Future researchers should investigate the impact of formal relationship commitments on GLB couples and their families (i.e., marriage, civil commitments, gay fathering). As society becomes more tolerant of civil unions and same sex marriages, there may be additional future opportunities to explore not only the unique attributes that differentiate same sex partnerships from heterosexual partnerships, but also the partnerships between two men and two women. Furthermore, a movement away from deficitbased perspectives could open a new lens on family life. Rather than applying research formulated from samples of heterosexual couples towards same sex couples, CFT therapists may soon have the opportunity to utilize findings related to GLB couples to enhance their understanding or treatment of heterosexual couples (i.e. concepts of flexible gender roles, families-of-choice not based on traditional ties such as birth or marriage). In addition, issues and content specific to transsexuals and persons that identify as transgender have been missing from the literature. Future researchers should conduct an analysis on transsexual and transgender content in order for the field of couple and family therapy to have an accurate assessment of the amount and quality of work that exists in this area. 
The methodology used in the GLB literature remained very similar to that in the original study. The largest proportion of literature was clinically or theoretically based. Clinical literature is vital to the field in order for clinicians to gain new skills and knowledge as well as for educators to have models to present to student therapists. That being said, the authors recommend that researchers conduct more empirical studies on GLB issues and specific approaches to treatment to strengthen the scientific merit of the literature. Given that very little exists in the literature about the experience of being a sexual minority and the structure and dynamics of GLB families and relationships, it is also appropriate to utilize qualitative and mixed methods to create a knowledge base of these fundamental issues.

It is beyond the scope of the current study to rigorously evaluate the quality of the GLB articles published. Because a number of articles were excluded from analysis due to being nonempirical (e.g. case studies, therapeutic treatment guidelines, supervision issues), it would be beneficial for scholars to develop appropriate evaluation tools for such articles in order to establish rigorous methods in evaluation that will comprehensively assess the quality of research available to practitioners and therapists.

This analysis also investigated the use of theory in the GLB literature. Overall, the use of theory is lacking with only one-third of reviewed articles citing a particular theory. To strengthen the research on GLB issues as well as the general research base of CFT, it is recommended that the use of theory is increased. Regardless, the theories used were largely family systems theories, including narrative, Bowen, and feminist family therapy, as well as ecological and family systems theories. Researchers should continue to expand such theories to include GLB families and relationships.

\section{Conclusion}


The current study findings suggest that there has been a substantial increase in attention paid to GLB population since 1997. Such an increase should be encouraging to therapists working with GLB clients and educators that supervise and train CFTs. However, the scope of GLB-related CFT research base is narrow and very shallow. Therefore, family scholars should strengthen the rigor of GLB-related research through using strong research designs, broadening the methods used (e.g. quantitative, qualitative and mixed-methods), and explicitly using and expanding family theory so that the field can continue to develop a rich picture of the lives of GLB persons. Although the field of CFT is coming out of the dark regarding the study of GLB issues, we must continue to move towards the light at the end of the heterocentric tunnel. 


\section{References}

American Association for Marriage and Family Therapy. (2005a). Report from the board on relationships, health, and marriage. Alexandria, VA: Author.

American Association for Marriage and Family Therapy. (2005b). What is marriage and family therapy? Alexandria, VA: Author.

American Association for Marriage and Family Therapy. (2005c). Version 11 accreditation standards. Alexandria, VA: Author. Retrieved from http://www.aamft.org/about /coamfte/Version\%2011\%20Standards/Master_Version_11_Accreditation_Standards.pdf.

Buhrke, R. A., Ben-Ezra, L. A., Hurley, M. E., \& Ruprecht, L. J. (1992). Content analysis and methodological critique of articles concerning lesbian and gay male issues in counseling journals. Journal of Counseling Psychology, 39, 91-99.

Clark, W., \& Serovich, J. M. (1997). Twenty years and still in the dark? Content analysis of articles pertaining to gay, lesbian, and bisexual issues in marriage and family therapy. Journal of Marital and Family Therapy, 22, 239-253.

Doherty, W. J., \& Simmons, D. S. (1996). Clinical practice patterns of marriage and family therapists: A national survey of therapists and their clients. Journal of Marital and Family Therapy, 22, 9-26.

Green, S. K., \& Bobele, M. (1994). Family therapists' response to AIDS: An examination of attitudes, knowledge, and contact. Journal of Marital and Family Therapy, 20, 349-367.

Henke, T., Carlson, T. S., \& McGeorge, C. R. (2009). Homophobia and clinical competency: An exploration of couple and family therapists' beliefs. Journal of Couple and Relationship Therapy, 8, 325-342. 
Human Rights Campaign. (2010). Marriage Equality \& Other Relationship Recognition Laws [Map]. Retrieved from http://www.hrc.org/documents/Relationship_Recognition_ Laws_Map.pdf

Laird, J., \& Green, R. J. (Eds.). (1995). Lesbians and gays in couples and families: A handbook for therapists. San Francisco: Jossey-Bass.

Lawrence v. Texas, 539 U.S. 558 (2003).

Long, J. K. (1996). Working with lesbians, gays, and bisexuals: Addressing heterosexism in supervision. Family Process, 35, 377-388.

Long, J. K. (2000). Are supervisors still in the dark? Supervision of gay, lesbian and bisexual clients. Readings in family therapy supervision, (pp. 46-49). Washington, DC: AAMFT.

Long, J. K., \& Serovich, J. M. (2003). Incorporating sexual orientation into MFT training programs: Infusion and inclusion. Journal of Marital and Family Therapy, 29, 59-67.

Morin, S. F. (1977). Heterosexual bias in psychological research on lesbianism and male homosexuality. American Psychologist, 32, 629-637.

Watters, A. T. (1986). Heterosexual bias in psychological research on lesbianism and male homosexuality (1979-1983), utilizing the bibliographic and taxonomic system of Morin (1977). Journal of Homosexuality, 13, 35-58. 
Table 1

Number of Gay, Lesbian, and Bisexual (GLB)Articles Published by Journal

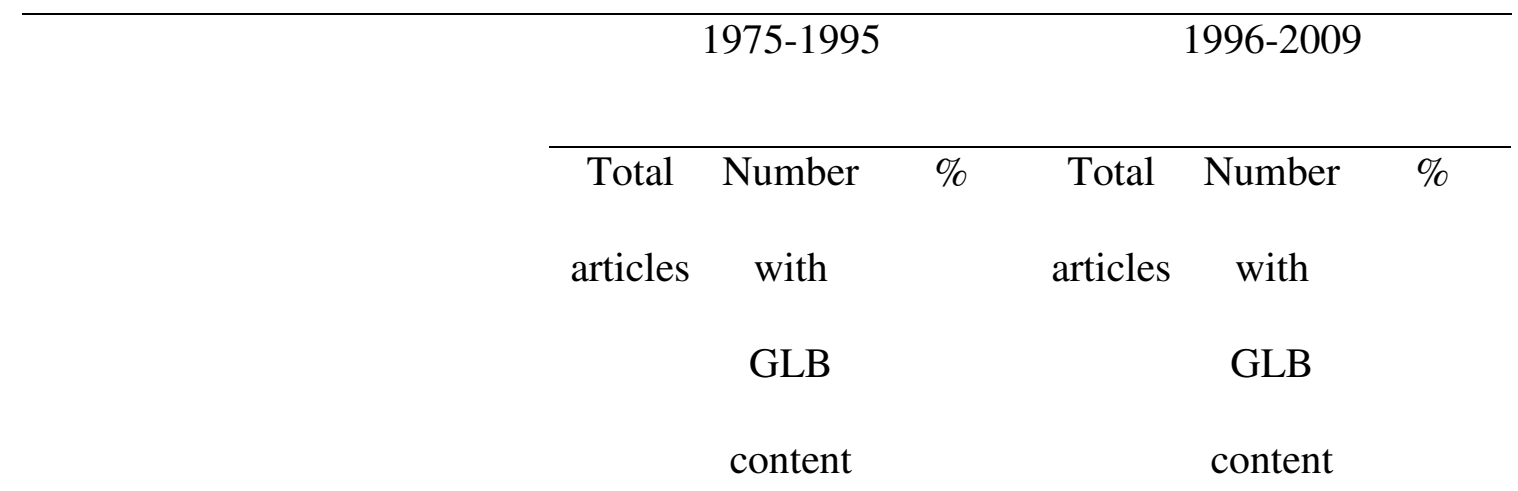

Journal title

\begin{tabular}{lllllll}
\hline American Journal of Family & 588 & 2 & $0.3 \%$ & 401 & 12 & $3.0 \%$
\end{tabular}

Therapy

\begin{tabular}{|c|c|c|c|c|c|c|}
\hline Behavior Therapy & 1199 & 9 & $0.8 \%$ & 541 & 0 & $0.0 \%$ \\
\hline Cognitive Therapy & 884 & 0 & $0.0 \%$ & 680 & 4 & $0.6 \%$ \\
\hline Contemporary Family & 477 & 2 & $0.4 \%$ & 410 & 5 & $1.2 \%$ \\
\hline \multicolumn{7}{|l|}{ Therapy } \\
\hline Families, Systems, \& Health & 422 & 0 & $0.0 \%$ & 366 & 2 & $0.5 \%$ \\
\hline Family Process & 796 & 2 & $0.3 \%$ & 439 & 9 & $2.1 \%$ \\
\hline Family Relations & 1383 & 11 & $0.8 \%$ & 651 & 13 & $2.0 \%$ \\
\hline Family Therapy & 518 & 1 & $0.2 \%$ & 180 & 7 & $3.9 \%$ \\
\hline Journal of Consulting and & 3286 & 17 & $0.5 \%$ & 1582 & 21 & 1.3 \\
\hline
\end{tabular}




\section{Clinical Psychology}

Journal of Couple and

Relationship Therapy

Journal of Family Psychology

Journal of Family

Psychotherapy

Journal of Family Therapy

Journal of Feminist Family

Therapy

Journal of Marital and Family

Therapy

Journal of Psychotherapy and the Family

Journal of Sex and Marital

$\mathrm{n} / \mathrm{a}$

$\mathrm{n} / \mathrm{a}$

$\mathrm{n} / \mathrm{a}$

475

$10 \quad 2.1 \%$
116

$0.0 \%$

263

$19 \quad 7.2 \%$
453

148

823

181 $\mathrm{n} / \mathrm{a}$

$\mathrm{n} / \mathrm{a}$

$\mathrm{n} / \mathrm{a}$

Therapy

Psychotherapy

153

$14 \quad 0.9 \%$

604

$13 \quad 2.2 \%$

13217

77

$\begin{array}{llll}0.6 \% & 8781 & 173 & 2.0 \%\end{array}$


Table 2

Distribution of Gay, Lesbian, and Bisexual Literature by Journal and Year

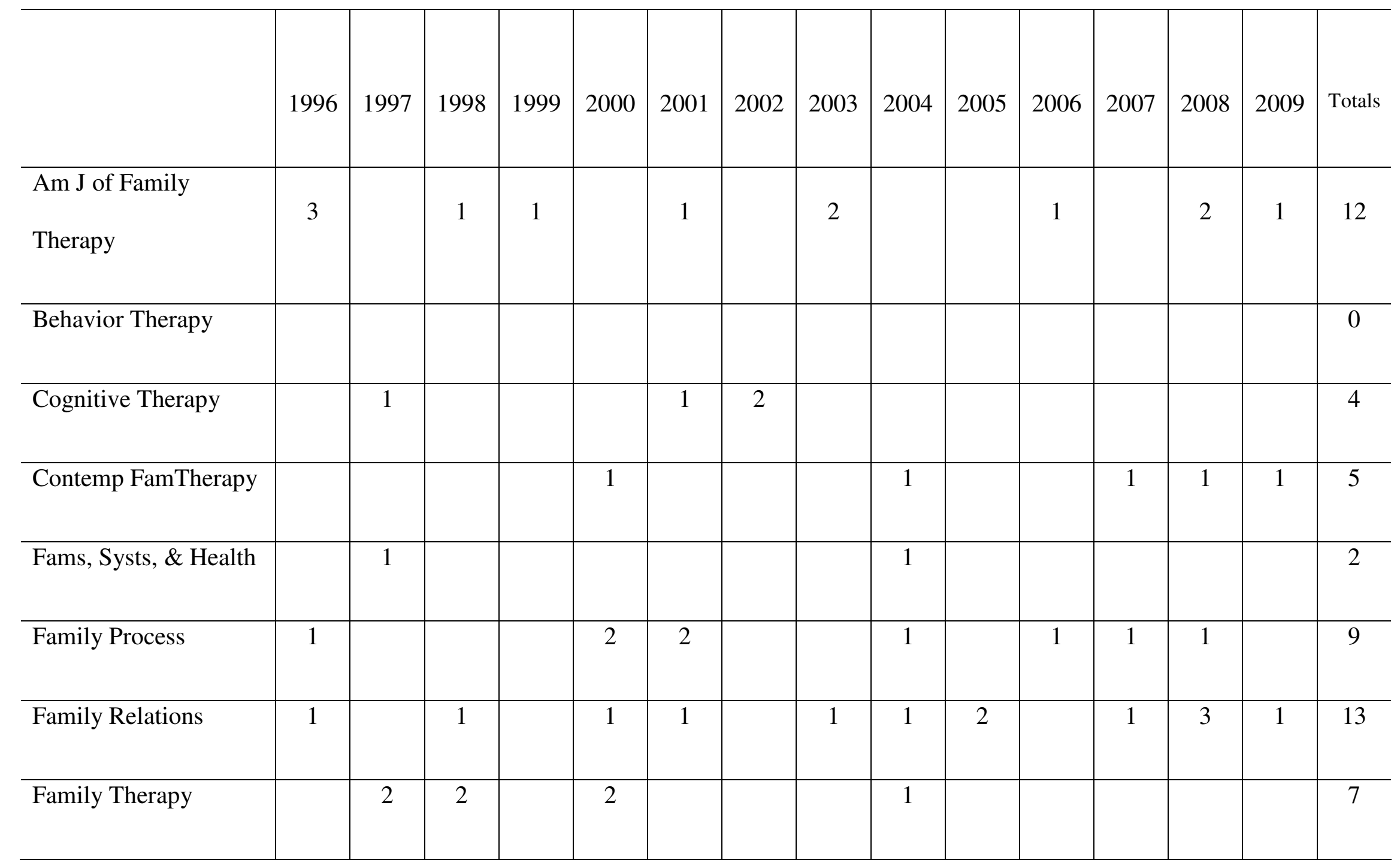




\begin{tabular}{|c|c|c|c|c|c|c|c|c|c|c|c|c|c|c|c|}
\hline $\begin{array}{l}\text { J of Cons and Clin } \\
\text { Psych }\end{array}$ & & 2 & 1 & 2 & 3 & 3 & 1 & 1 & & 1 & & 2 & 2 & 3 & 21 \\
\hline $\begin{array}{l}\text { J of Couple \& Rel } \\
\text { Ther }\end{array}$ & & & & & & & & 2 & 11 & 2 & 1 & 2 & & 1 & 19 \\
\hline $\begin{array}{l}\text { J of Family } \\
\text { Psychology }\end{array}$ & 1 & 2 & 1 & & & & 2 & 3 & 1 & & 1 & & 3 & 2 & 16 \\
\hline $\begin{array}{l}\text { J of Fam } \\
\text { Psychotherapy }\end{array}$ & 1 & & & 1 & 1 & & & 1 & & & & & & & 4 \\
\hline $\mathrm{J}$ of Family Therapy & & 1 & & 2 & & & & & 1 & & 1 & & & 1 & 6 \\
\hline $\begin{array}{l}\text { J of Feminist Fam } \\
\text { Ther }\end{array}$ & 1 & & 1 & & & 1 & & 2 & 1 & & 7 & & 2 & & 15 \\
\hline JMFT & & 1 & 1 & 1 & 5 & 1 & 1 & 3 & & 1 & 1 & & 2 & & 17 \\
\hline $\mathrm{J}$ of Sex \& Marital & 1 & 1 & 2 & 1 & & 1 & & & & 4 & & & & & 10 \\
\hline
\end{tabular}




\begin{tabular}{l|c|c|c|c|c|c|c|c|c|c|c|c|c|c|c}
\hline Ther & & & & & & & & & & & & & & & \\
\hline Psychotherapy & 1 & 1 & 2 & & & 1 & 1 & 1 & 1 & 3 & 1 & 1 & \\
\hline Totals & 10 & 12 & 12 & 8 & 15 & 12 & 7 & 16 & 20 & 13 & 14 & 8 & 16 & 10 & 173 \\
\hline
\end{tabular}


Table 3

Percentage Distribution of Morin's (1977) Original Categories

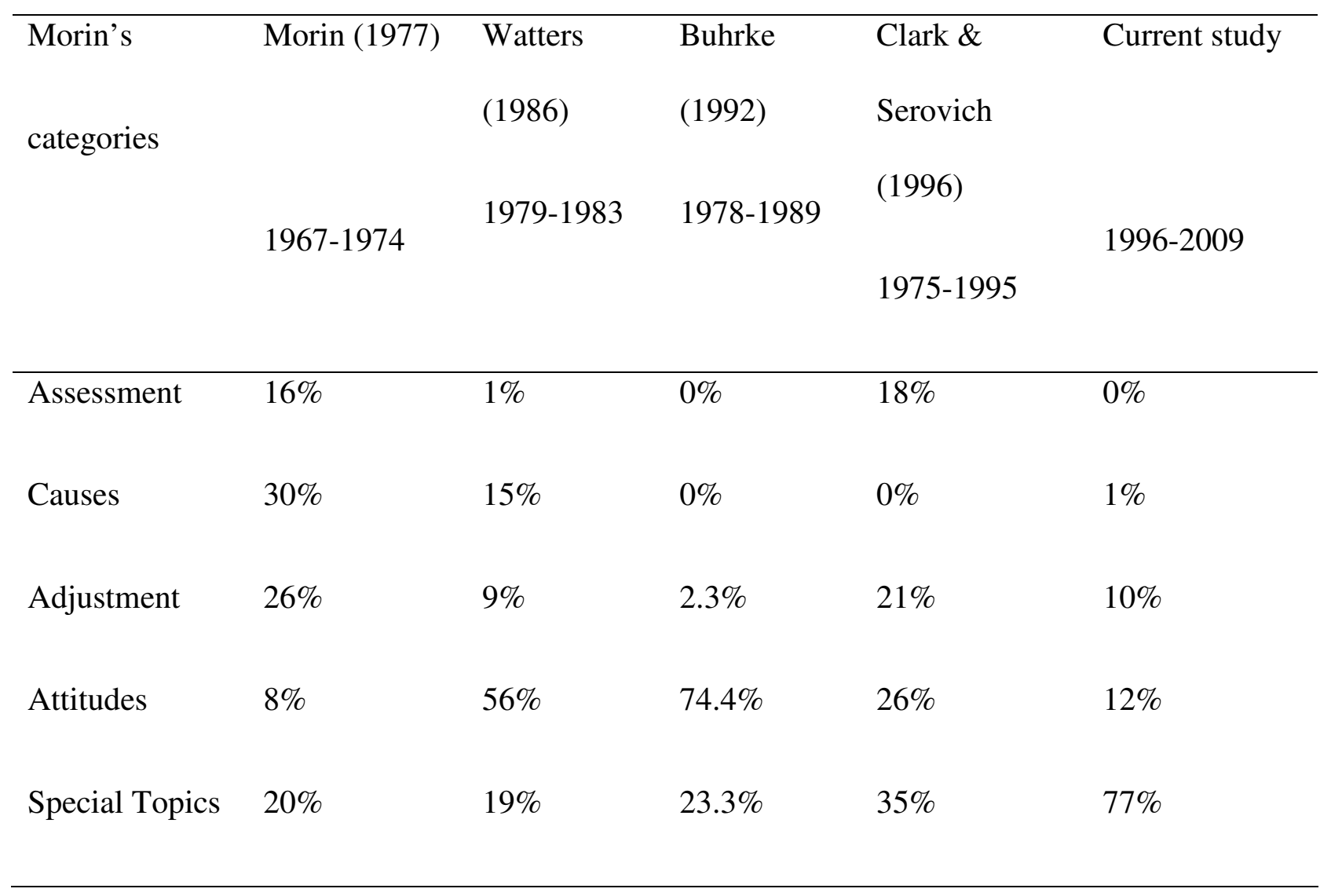


Table 4

Morin's (1977) Categories for Future Research

Number of articles in couple and family therapy journals

Morin's (1977) areas for

future research

1975-1995

1996-2009

Dynamics of gay/lesbian

$22(28.6 \%)$

$52(30 \%)$

relationships

Development of positive identity $12(15.6 \%)$

$18(10.4 \%)$

Variables associated with coming $7(10 \%)$

$13(7.5 \%)$

out

Degree of identity and commitment $2(2 \%)$

$3(1.7 \%)$

Children/adolescent issues

$10(13 \%)$

$10(5.8 \%)$

Civil liberties

0

$5(2.9 \%)$

Aging

$1(1 \%)$

$1(.6 \%)$

Attitudinal change

$13(16.8 \%)$

$14(8 \%)$

Nature and meaning of

$10(13 \%)$

$6(3.5 \%)$

homosexuality 
None

$\mathrm{n} / \mathrm{a}$

$51(29.6 \%)$ 
Table 5

Couple and Family Therapy Categories

Number of articles in couple and family therapy journals

Clark \& Serovich (1996) categories

1975-1995 1996-2009

Therapy with GLB clients

$8(10.4 \%)$

$40(23.1 \%)$

Other

$8(10.4 \%)$

$28(16.2 \%)$

AIDS-related

$9(11.6 \%)$

$27(15.6 \%)$

Parenting issues

$8(10.4 \%)$

$15(8.7 \%)$

Relationship quality/satisfaction- empirically measured

$7(9 \%)$

$11(6.4 \%)$

Dynamics of GLB relationships- theoretical articles

$7(9 \%)$

$10(5.8 \%)$

Family of origin issues

$3(3.9 \%)$

$10(5.8 \%)$

Attitudes about homosexuality- therapists and family

$5(6.5 \%)$

members

$8(4.6 \%)$

GLB identity

$4(5.2 \%)$

$6(3.5 \%)$

Treatment of homosexuality/Attempts to "change" or

$13(16.8 \%) \quad 5(2.9 \%)$ 
"cure"

Relationship issues (i.e. straight women/gay men)

$1(1.2 \%) \quad 5(2.9 \%)$

+/- aspects of coming out

$3(3.9 \%) \quad 4(2.3 \%)$

Sexual function/dysfunction

$1(1.2 \%)$

$4(2.3 \%)$ 
Table 6

Percentage Distribution of Methodology

Type of study Number of articles in couple and

family therapy journals

1975-1995 1996-2009

\begin{tabular}{lll}
\hline Clinical/theoretical & $35(44 \%)$ & $76(43.9 \%)$ \\
Quantitative & $26(32 \%)$ & $68(39.3 \%)$ \\
Qualitative & $9(15 \%)$ & $23(13.3 \%)$ \\
Mixed Methods & $7(9 \%)$ & $5(2.9 \%)$ \\
\end{tabular}




\section{Appendix}

Allen, K. R. (2007). Ambiguous loss after lesbian couples with children break up: A case for same-gender divorce. Family Relations, 56, 175-183.

Antoni, M. H., Cruess, D. G., Cruess, S., Lutgendorf, S., Kumar, M., Ironson, G., \& Scneiderman, N. (2000). Cognitive-behavioral stress management intervention effects on anxiety, 24-hr urinary norepinephrine output, and t-cytotoxic/suppressor cells over time among symptomatic HIV-infect gay men. Journal of Consulting and Clinical Psychology, $68,31-45$.

Ariel, J., \& McPherson, D. W. (2000). Therapy with lesbian and gay parents and their children. Journal of Marital and Family Therapy, 26, 421-432.

Armesto, J. C., \& Weisman, A. G. (2001). Attributions and emotional reactions to the identity disclosure (“coming out”) of a homosexual child. Family Process, 40, 145-161.

Baptist, J. A., \& Allen, K. R. (2008). A family's coming out process: Systemic change and multiple realities. Contemporary Family Therapy, 30, 92-110.

Baron, J. (1996). Some issues in psychotherapy with gay and lesbian clients. Psychotherapy, 33, 611-616.

Beckerman, N. L. (2000). Couples of mixed HIV status: Bowenian contributions to an assessment framework. Family Therapy, 27, 19-32.

Beeler, J., \& DiProva, V. (1999). Family adjustment following disclosure of homosexuality by a member: Themes discerned in narrative accounts. Journal of Marital and Family Therapy, $25,443-459$.

Bepko, C., \& Johnson, T. (2000). Gay and lesbian couples in therapy: Perspectives for the contemporary family therapist. Journal of Marital and Family Therapy, 26, 409-419. 
Bernstein, A. C. (2000). Straight therapists working with lesbians and gays in family therapy. Journal of Marital and Family Therapy, 26, 443-454.

Bettinger, M. (2004). A systems approach to sex therapy with gay male couples. Journal of Couple and Relationship Therapy, 3, 65-74.

Bettinger, M. (2005). A family systems approach to working with sexually open gay male couples. Journal of Couple and Relationship Therapy, 4, 149-160.

Bigner, J. J. (2004). Working with gay and lesbian parents. Journal of Couple and Relationship Therapy, 3, 85-93.

Bogaert, A. F. (2005). Gender role/identity and sibling sex ratio in homosexual men. Journal of Marital and Family Therapy, 31, 217-227.

Bor, R., \& du Plessis, P. (1997). The impact of HIV/AIDS on families: An overview of recent research. Families, Systems, and Health, 15, 413-427.

Bor, R., du Plessis, P., \& Russell, M. (2004). The impact of disclosure of HIV on the index patient's self-defined family. Journal of Family Therapy, 26, 167-192.

Bower, J. E., Kemeny, M. E., Taylor, S. E., \& Fahey, J. L. (1998). Cognitive processing, discovery of meaning, CD4 decline, and AIDS-related mortality among bereaved HIVseropositive men. Journal of Consulting and Clinical Psychology, 66, 979-986.

Bradford, M. (2004). Bisexual issues in same-sex couple therapy. Journal of Couple and Relationship Therapy, 3, 43-52.

Bricker, M. E., \& Horne, S. G. (2007). Gay men in long-term relationships: Impact of monogamy and nonmonogamy on relational health. Journal of Couple and Relationship Therapy, 6, 27-47. 
Bruss, K. V., \& Glickauf-Hughes, C. (1997). Co-dependency issues in the termination of lesbian relationships. Family Therapy, 24, 9-18.

Buchanan, M., Dzelme, K., Harris, D., \& Hecker, L. (2001). Challenges of being simultaneously gay or lesbian and spiritual and/or religious: A narrative perspective. The American Journal of Family Therapy, 29, 435-449.

Burckell, L. A., \& Goldfried, M. R. (2006). Therapists qualities preferred by sexual minority individuals. Psychotherapy, 43, 32-49.

Burgoyne, R. W. (2001). The relationship assessment measure for same-sex couples (RAMSSC): A standardized instrument for evaluating gay couple functioning. Journal of Sex and Marital Therapy, 27, 279-287.

Butler, C. (2009). Sexual and gender minority therapy and systemic practice. Journal of Family Therapy, 31, 338-358.

Buxton, A. P. (2004). Paths and pitfalls: How heterosexual spouses cope when their husbands or wives come out. Journal of Couple and Relationship Therapy, 3, 95-109.

Chabot, J. M., \& Ames, B. D. (2004). "It wasn't 'let's get pregnant and go do it':” Decision making in lesbian couples planning motherhood via donor insemination. Family Relations, $53,348-356$.

Chan, R. W., Brooks, R. C., Raboy, B., \& Patterson, C. J. (1998). Division of labor among lesbian and heterosexual parents: Associations with children's adjustment. Journal of Family Psychology, 12, 402-419.

Charles, L. L., Thomas, D., \& Thornton, M. L. (2005). Overcoming bias toward same-sex couples: A case study from inside an MFT ethics classroom. Journal of Marital and Family Therapy, 31, 239-249. 
Clark, W. M. (1998). Becoming an outsider within: Reflections on professional and personal identity development as a lesbian-feminist marriage and family therapist. Journal of Feminist Family Therapy, 10, 57-63.

Clark, W., \& Serovich, J. M. (1997). Twenty years and still in the dark? Content analysis of articles pertaining to gay, lesbian, and bisexual issues in marriage and family therapy. Journal of Marital and Family Therapy, 22, 239-253.

Cochran, S. D., Keenan. C., Schober, C., \& Mays, V. M. (2000). Estimates of alcohol use and clinical treatment needs among homosexually active men and women in the United States population. Journal of Consulting and Clinical Psychology, 68, 1062-1071.

Cochran, S. D., Mays, V. M., Alegria, M., Ortega, A. N., \& Takeuchi, D. (2007). Mental health and substance use disorders among Latino and Asian American lesbian, gay, and bisexual adults. Journal of Consulting and Clinical Psychology, 75, 785-794.

Cochran, S. D., Sullivan, J. G., \& Mays, V. M. (2003). Prevalence of mental disorders, psychological distress, and mental health services use among lesbian, gay, and bisexual adults in the United States. Journal of Consulting and Clinical Psychology, 71, 53-61.

Collins, K. W. (1998). Bisexuality: A review of current research. Family Therapy, 25, 1-11. Connolly, C. M. (2004). Clinical issues with same-sex couples: A review of the literature. Journal of Couple and Relationship Therapy, 3, 3-12.

Connolly, C. M. (2004). Lesbian couples: A qualitative look at long-term love. Journal of Couple and Relationship Therapy, 3, 13-26.

Connolly, C. M. (2006). A feminist perspective of resilience in lesbian couples. Journal of Feminist Family Therapy, 18, 137-162. 
Crisp, D., Priest, R., \& Torgerson, A. (1998). African-American gay men: Developmental issues, choices, and self-concept. Family Therapy, 25, 161-168.

Crosbie-Burnett, M., Foster, T. L., Murray, C. I., \& Bowen, G. L. (1996). Gays’ and lesbians’ families-of-origin: A social-cognitive-behavioral model of adjustment. Family Relations, 45, 397-403.

Cruess, S., Antoni, M. H., Hayes, A., Penedo, F., Ironson, G., Fletcher, M. A., Lutgendorf, S., \& Schneiderman. (2002). Changes in mood and depressive symptoms and related change processes during cognitive-behavioral stress management in HIV-infected men. Cognitive Therapy, 26, 373-392.

Damon, W., \& Rosser, B. R. S. (2005). Anodyspareunia in men who have sex with men: Prevalence, predictors, consequences, and the development of DSM diagnostic criteria. Journal of Sex and Marital Therapy, 31, 129-141.

Deacon, S. A., Reinke, L., \& Viers, D. (1996). Cognitive-behavioral therapy for bisexual couples: Expanding the realms of therapy. The American Journal of Family Therapy, 24, 242-250.

Doherty, W. J., \& Simmons, D.S. (1996). Clinical practice patterns of marriage and family therapists: A national survey of therapists and their clients. Journal of Marital and Family Therapy, 22, 9-26.

Elizur, Y., \& Ziv, M. (2001). Family support and acceptance, gay male identity formation, and psychological adjustment: A path model. Family Process, 40, 125-144.

Fletcher, A. C., \& Russell, S. T. (2001). Incorporating issues of sexual orientation in the classroom: Challenges and solutions. Family Relations, 50, 34-40. 
Ford, D., \& Priest, R. (2004). Clinical issues surrounding disclosure of homosexuality: An introduction. Family Therapy, 31, 95-103.

Giddings, L. (2006). Reflection: “Girls can’t marry other girls.” Journal of Feminist Family Therapy, 18, 163-166.

Godfrey, K., Haddock, S. A., Fisher, A., \& Lund, L. (2006). Essential components of curricula for preparing therapists to work effectively with lesbian, gay, and bisexual clients: A delphi study. Journal of Marital and Family Therapy, 32, 491-504.

Goldberg, A. E., \& Smith, J. Z. (2008). Social support and psychological well-being in lesbian and heterosexual preadoptive couples. Family Relations, 57, 281-294.

Goldberg, A. E., \& Smith, J. Z. (2009a). Perceived parenting skill across the transition to adoptive parenthood among lesbian, gay, and heterosexual couples. Journal of Family Psychology, 23, 861-870.

Goldberg, A. E., \& Smith, J. Z. (2009b). Predicting non-Arican American lesbian and heterosexual preadoptive couples' openness to adopting an African American child. Family Relations, 58, 346-360.

Golding, A. C. (2006). Redefining the nuclear family: An exploration of resiliency in lesbian parents. Journal of Feminist Family Therapy, 18, 35-65.

Green, R. -J. (2000). “Lesbians, gay men, and their parents:” A critique of LaSala and the prevailing clinical "wisdom.” Family Process, 39, 257-266.

Green, M. S., Murphy, M. J., Blumer, M., \& Palmanteer, D. (2009). Marriage and family therapists' comfort level working with gay and lesbian individuals, couples, and families. The American Journal of Family Therapy, 37, 159-168. 
Hall, M. (2004). Resolving the curious paradox of the (a)sexual lesbian. Journal of Couple and Relationship Therapy, 3, 75-83.

Hare, J., \& Skinner, D. (2008). "Whose child is this?”: Determining legal status for lesbian parents who used assisted reproductive technologies. Family Relations, 57, 365-375.

Heatherington, L., \& Lavner, J. A. (2008). Coming to terms with coming out: Review and recommendations for family systems-focused research. Journal of Family Psychology, 22, 329-343.

Henke, T., Carlson, T. S., \& McGeorge, C. R. (2009). Homophobia and clinical competency: An exploration of couple and family therapists' beliefs. Journal of Couple and Relationship Therapy, 8, 325-342.

Hepworth, J. (1999). The two-way mirror in my therapy room: AIDS and families. Journal of Family Psychotherapy, 10, 9-20.

Herek, G. M., Gillis, J. R., \& Cogan, J. C. (1999). Psychological sequelae of hate-crime victimization among lesbian, gay, and bisexual adults. Journal of Consulting and Clinical Psychology, 67, 945-951.

Hernandez, P., Rickard, J., \& Giambruno, P. (2008). Transformative family therapy with a lesbian couple: A case study. Journal of Feminist Family Therapy, 20, 281-298.

Hernandez, P., \& Rankin, P., IV. (2008). Relational safety and liberating training spaces: An application with a focus on sexual orientation issues. Journal of Marital and Family Therapy, $34,251-264$.

Johnson, J. G., Alloy, L. B., Panzarella, C., Metalsky, G. I., Rabkin, J. G., Williams, J. B. W., \&Abramson, L. Y. (2001). Hopelessness as a mediator of the association between social 
support and depressive symptoms: Finding of a study of men with HIV. Journal of Consulting and Clinical Psychology, 69, 1056-1060.

Johnson, M. O., Carrico, A. W., Chesney, M. A., \& Morin, S. F. (2008). Internalized heterosexism among HIV-positive, gay-identified men: Implications for HIV prevention and care. Journal of Consulting and Clinical Psychology, 76, 829-839.

Jones, M. A., Botsko, M., \& Gorman, B. S. (2003). Predictors of psychotherapeutic benefit of lesbian, gay, and bisexual clients: The effects of sexual orientation matching and other factors. Psychotherapy, 40, 289-301.

Julien, D., Chartrand, E., \& Begin, J. (1996). Male couples' dyadic adjustment and the use of safer sex within and outside of primary relationship. Journal of Family Psychology, 10, 8996.

Julien, D., Chartrand, E., Simard, M. -C., Bouthillier, D., \& Begin, J. (2003). Conflict, social support, and relationship quality: An observational study of heterosexual, gay male, and lesbian couples' communication. Journal of Family Psychology, 17, 419-428.

Kalichman, S. C., Kelly, J. A., Morgan, M., \& Rompa, D. (1997). Fatalism, current life satisfaction, and risk for HIV infection among gay and bisexual men. Journal of Consulting and Clinical Psychology, 65, 542-546.

Kilgore, H., Sideman, L., Amin, K., Baca, L., \& Bohanske, B. (2005). Psychologists’ attitudes and therapeutic approaches toward gay, lesbian, and bisexual issues continue to improve: An update. Psychotherapy, 42, 395-400.

Kimberly, J. A., \& Serovich, J. M. (1996). Perceived social support among people living with HIV/AIDS. The American Journal of Family Therapy, 24, 41-53. 
Kimmel, S. B., \& Mahalik, J. R. (2005). Body image concerns of gay men: The roles of minority stress and conformity to masculine norms. Journal of Consulting and Clinical Psychology, 73, 1185-1190.

Knudson-Martin, C., \& Laughlin, M. J. (2005). Gender and sexual orientation in family therapy: Toward a postgender approach. Family Relations, 54, 101-115.

Kozlowski, N. F., Rupert, P. A., \& Crawford, I. (1998). Psychotherapy with HIV-infected clients: Factors influencing notification of third parties. Psychotherapy, 35, 105-115.

Kranz, K. C., \& Daniluk, J. C. (2006). Living outside of the box: Lesbian couples with children conceived through the use of anonymous donor insemination. Journal of Feminist Family Therapy, 18(1), 1-33.

Kurdek, L. A. (1997). Relation between neuroticism and dimensions of relationship commitment: Evidence from gay, lesbian, and heterosexual couples. Journal of Family Psychology, 11(1), 109-124.

Kurdek, L. A. (1997). The link between facets of neuroticism and dimensions of relationship commitment: Evidence from gay, lesbian, and heterosexual couples. Journal of Family Psychology, 11(4), 503-514.

Kurdek, L. A. (2008). Change in relationship quality for partners from lesbian, gay, and heterosexual couples. Journal of Family Psychology, 22(5), 701-711.

Laird, J. (2000). Gender in lesbian relationships: Cultural, feminist, and constructionist reflections. Journal of Marital and Family Therapy, 26(4), 455-467.

LaSala, M. C. (2000). Lesbians, gay men, and their parents: Family therapy for the coming-out crisis. Family Process, 39(1), 67-81. 
LaSala, M. C. (2002). Walls and bridges: How coupled gay men and lesbians manage their intergenerational relationships. Journal of Marital and Family Therapy, 28(3), 327-339).

Leask, C., Elford, J., Bor, R., Miller, R., \& Johnson, M. (1997). Selective disclosure: A pilot investigation into changes in family relationships since HIV diagnosis. Journal of Family Therapy, 19, 59-69.

Liddle, B. J. (1997). Gay and lesbian clients' selection of therapists and utilization of therapy. Psychotherapy, 34(1), 11-18.

Liszcz, A. M., \& Yarhouse, M. A. (2005) Same-sex attraction: A survey regarding clientdirected treatment goals. Psychotherapy, 42(1), 111-115.

Littlefield, G. D., Lim, M., Canada, R. M., \& Jennings, G. (2000). Common themes in long-term lesbian relationships. Family Therapy, 27, 71-79.

Long, J. K. (1996). Working with lesbians, gays, and bisexuals: Addressing heterosexism in supervision. Family Process, 35, 377-388.

Long, J. K. (2000). Are supervisors still in the dark? Supervision of gay, lesbian, and bisexual clients. Readings in family therapy supervision, (pp. 46-49). Washington, DC: AAMFT.

Long, J. K., \& Andrews, B. V. (2007). Fostering strength and resiliency in same-sex couples: An overview. Journal of Couple and Relationship Therapy, 6, 153-165.

Long, J. K., \& Lindsey, E. (2004). The sexual orientation matrix for supervision: A tool for training therapists to work with same-sex couples. Journal of Couple and Relationship Therapy, 3, 123-135.

Long, J. K., \& Serovich, J. M. (2003). Incorporating sexual orientation into MFT training programs: Infusion and inclusion. Journal of Marital and Family Therapy, 29, 59-67. 
Lutgendorf, S. K., Antoni, M. H., Ironson, G., Klimas, N., Fletcher, M. A., \& Schneiderman, N. (1997). Cognitive processing style, mood, and immune function following HIV seropositivity notification. Cognitive Therapy and Research, 21(2) 157-184.

Lutgendorf, S. K., Antoni, M. H., Ironson, G., Klimas, Kumar, M., Starr, K., \& McCabe, P. (1997) Cognitive-behavioral stress management decreases dysphoric mood and herpes simplex virus-type 2 antibody titers in symptomatic HIV-seropositive gay men. Journal of Consulting and Clinical Psychology, 65(1), 31-43.

MacDonald, B. J. (1998). Issues in therapy with gay and lesbian couples. Journal of Sex and Marital Therapy, 24, 165-190.

Malley, M., \&Tasker, F. (1999). Lesbians, gay men and family therapy: A contradiction in terms? Journal of Family Therapy, 21, 3-29.

Mazor, A. (2004). Same-gender couple therapy: Creating new objects in intimacy and parenthood transition. Contemporary Family Therapy, 26(4), 409-423.

McLean, R., \& Marini, I. (2003). Counseling issues and approaches working with families of African-American gay male members with HIV/AIDS. Journal of Family Psychotherapy, $14(1), 9-21$.

Meana, M., Rakipi, R. S., Weeks, G., \& Lykins, A. (2006). Sexual functioning in non-clinical sample of partnered lesbians. Journal of Couple and Relationship Therapy, 5, 1-22.

Means-Christensen, A. J., Snyder, D. K., \& Negy, C. (2003). Assessing nontraditional couples: Validity of the marital satisfaction inventory-Revised with gay, lesbian, and cohabiting heterosexual couples. Journal of Marital and Family Therapy, 29(1), 69-83. 
Merlis, S. R., \& Linville, D. (2006). Exploring a community's response to lesbian domestic violence through the voices of providers: A qualitative study. Journal of Feminist Family Therapy, 18(1), 97-136.

Miller, A. J., Bobner, R. F., \& Zarski, J. J. (2000). Sexual identity development: A base for work with same-sex couple partner abuse. Contemporary Family Therapy, 22(2), 189-200

Mize, L. K., Turell, S., \& Meier, J. (2004). Sexual orientation and the sister relationship: Conversations and opportunities. Journal of Feminist Family Therapy, 16(4), 1-19.

Morgenstern, J., Bux Jr., D. A., Parsons, J., Hagman, B. T., Wainberg, M., \& Irwin, T. (2009). Randomized trial to reduce club drug use and HIV risk behaviors among men who have sex with men. Journal of Consulting and Clinical Psychology, 77(4), 645-656

Morgenstern, J., Irwin, T. W., Wainberg, M. L., Parsons, J. T., Muench, F., Bux Jr., D. A., \& Kahler, C. W. (2007). A randomized controlled trial of goal choice interventions for alcohol use disorders among men who have sex with men. Journal of Consulting and Clinical Psychology, 75(1), 72-84.

Morris, J. F., Balsam, K. F., \& Rothblum, E. D. (2002). Lesbian and bisexual mothers and nonmothers: Demographics and the coming-out process. Journal of Family Psychology, $16(3), 144-156$.

Murray, C. E., \& Murray Jr., T. L. (2009). Reconsidering the term marriage in marriage and family therapy. Contemporary Family Therapy, 31, 209-221.

Nazario, A. (2003). Latino cross-cultural same sex male relationships: Issues of ethnicity, race, and other domains of influence. Journal of Couple and Relationship Therapy, 2(2), 103-113.

Negy, C., \& McKinney, C. (2006). Application of feminist therapy: Promoting resiliency among lesbian and gay families. Journal of Feminist Family Therapy, 18(1), 67-83. 
Neustifter, R. (2008). Common concerns faced by lesbian elders: An essential context for couple's therapy. Journal of Feminist Family Therapy, 20(3), 251-267.

Nord, D. (1996). The impact of multiple AIDS-related loss on families of origin and families of choice. The American Journal of Family Therapy, 24(2), 129-144.

Oldham, J. D., \& Kasser, T. (1999). Attitude change in response to information that male homosexuality has a biological basis. Journal of Sex and Marital Therapy, 25, 121-124.

Oswald, R. F. (2002). Inclusion and belonging in the family rituals of gay and lesbian people. Journal of Family Psychology, 16(4), 428-436.

Oswald, R. F., \& Culton, L. S. (2003). Under the rainbow: Rural gay life and its relevance for family providers. Family Relations, 52, 72-81.

Oswald, R. F., Goldberg, A., Kuvalanka, K., \& Clausell, E. (2008). Structural and moral commitment among same-sex couples: Relationship duration, religiosity, and parental status. Journal of Family Psychology, 22(3), 411-419.

Pachankis, J. E., \& Goldfried, M. R. (2004). Clinical issues in working with lesbian, gay, and bisexual clients. Psychotherapy, 41(3), 227-246.

Pachankis, J. E., Goldfried, M. R., \& Ramrattan, M. E. (2008). Extension of the rejection sensitivity construct to the interpersonal functioning of gay men. Journal of Consulting and Clinical Psychology, 76(2), 306-317.

Pais, S., Piercy, F., \& Miller, J. (1998). Factors related to family therapists' breaking confidence when clients disclose high-risks-to-HIV/AIDS sexual behaviors. Journal of Marital and Family Therapy, 24(4), 457-472. 
Palmer, R., \& Bor, R. (2001). The challenges to intimacy and sexual relationships for gay men in HIV serodiscordant relationships: A pilot study. Journal of Marital and Family Therapy, 27(4), 419-431.

Park, C.L., Folkman, S., \& Bostrom, A. (2001). Appraisals of controllability and coping in caregivers and HIV+ men: Testing the goodness-of-fit hypothesis. Journal of Consulting and Clinical Psychology, 69(3), 481-488.

Penedo, F.J., Antoni, M.H., Schneiderman, N., Ironson, G.H., Malow, R.M., Cruess, S., ... LaPerriere, A. (2001). Dysfunctional attitudes, coping, and depression among HIVseropositive men who have sex with men. Cognitive Therapy and Research, 25(5), 591-606.

Perlesz, A., Brown, R., Lindsay, J., McNair, R., deVaus, D., \& Pitts, M. (2006). Family in transition: Parents, children and grandparents in lesbian families give meaning to 'doing family.' Journal of Family Therapy, 28, 175-199.

Pintzuk, M.T. (2004). Identity and cultural narrative in a lesbian relationship. Journal of Couple \& Relationship Therapy, 3(2/3), 27-41.

Porche, M.V., \& Purvin, D.M. (2008). "Never in our lifetime”: Legal marriage for same-sex couples in long-term relationships. Family Relations, 57, 144-159.

Poteat, P.V., Aragon, S.R., Espelage, D.L., \& Koenig, B.W. (2009). Psychosocial concerns of sexual minority youth: Complexity and Caution in Group Differences. Journal of Consulting and Clinical Psychology, 77(1), 196-201.

Potoczniak, M.J., Mourot, J.E., Crosbie-Burnett, M., \& Potoczniak, D.J. (2003). Legal and psychological perspectives on same-sex domestic violence: A multisystemic approach. Journal of Family Psychology, 17(2), 252-259. 
Rasera, E.F., Vieira, E.M., \& Japur, M. (2004). Influence of gender and sexuality on the construction of being HIV positive: As experienced in a support group in Brazil. Families, Systems, \& Health, 22(3), 340-351.

Rayburn, N.R., \& Davison, G.C. (2002). Articulated thoughts about antigay hate crimes. Cognitive Therapy and Research, 26(4), 431-447.

Rosario, M., Schrimshaw, E.W., Hunter, J., \& Gwadz, M. (2002). Gay-related stress and emotional distress among gay, lesbian, and bisexual youths: A longitudinal examination. Journal of Consulting and Clinical Psychology, 70(4), 967-975.

Rosik, C.H. (2003). Motivational, ethical, and epistemological foundations in the treatment of unwanted homoerotic attraction. Journal of Marital and Family Therapy, 29(1), 13-28.

Rosser, S.B.R., Metz, M.E., Bockting, W.O., \& Buroker, T. (1997). Sexual difficulties, concerns, and satisfaction in homosexual men: An empirical study with implications for HIV prevention. Journal of Sex \& Marital Therapy, 23(1), 61-73.

Rosser, S.B.R., Short, B.J., Thurmes, P.J., \& Coleman, E. (1998). Anodyspareunia, the unacknowledged sexual dysfunction: A validation study of painful receptive anal intercourse and its psychosexual concomitants in homosexual men. Journal of Sex \& Marital Therapy, $24,281-262$.

Rostosky, S.S., Korfhage, B.A., Duhigg, J.M., Stern, A.J., Bennett, L., \& Riggle, E.D.B. (2004). Same-sex couple perceptions of family support: A consensual qualitative study. Family Process, 43(1), 43-57.

Rostosky, S.S., Riggle, E.D.B., Brodnicki, C., \& Olson, A. (2008). An exploration of lived religion in same-sex couples from Judeo-Christian traditions. Family Process, 47(3), 389403. 
Rothschild, P., Brownlee, K., \& Gallant, P. (2000). Narrative interventions for working with persons with AIDS: A case study. Journal of Family Psychotherapy, 11(3), 1-13.

Safren, S.A., \& Heimberg, R.G. (1999). Depression, hopelessness, suicidality, and related factors in sexual minority and heterosexual adolescents. Journal of Consulting and Clinical Psychology, 67(6), 859-866.

Saltzburg, S. (1996). Family therapy and the disclosure of adolescent homosexuality. Journal of Family Psychotherapy, 7(4), 1-18.

Saltzburg, S. (2007). Narrative therapy pathways for re-authoring with parents of adolescents coming-out as lesbian, gay, and bisexual. Contemporary Family Therapy, 29, 57-69.

Sanders, G.L, \& Kroll, I.T. (2000). Generating stories of resilience: Helping gay and lesbian youth and their families. Journal of Marital and Family Therapy, 26(4), 433-442.

Savin-Williams, R.C., \& Dubé, E.M. (1998). Parental reactions to their child's disclosure of a gay/lesbian identity. Family Relations, 47, 7-13.

Savin-Williams, R.C., \& Ream, G.L. (2003). Sex variations in the disclosure to parents of samesex attractions. Journal of Family Psychology, 17(3), 429-438.

Semple, S.J., Patterson, T.L., \& Grant, I. (2000). The Sexual negotiation behavior of HIVpositive gay and bisexual men. Journal of Consulting and Clinical Psychology, 68(5), 934937.

Serovich, J.M., Craft, S.M., Toviessi, P., Gangamma, R., McDowell, T., \& Grafsky, E.L. (2008). A Systematic review of the research base on sexual reorientation therapies. Journal of Marital and Family Therapy, 34(2), 227-238. 
Shehan, C.L., Uphold, C.R., Bradshaw, P., Bender, J., Arce, N., \& Bender, B. (2005). To tell or not to tell: Men's disclosure of their HIV-positive status to their mothers. Family Relations, 54, 184-196.

Shernoff, M. (2006). Negotiated nonmonogamy and male couples. Family Process, 45(4), 407418.

Sherry, A. (2007). Internalized homophobia and adult attachment: Implications for clinical practice. Psychotherapy: Theory, Research, Practice, Training, 44(2), 219-225.

Sherry, A., Whilde, M. R., \& Patton, J. (2005). Gay, lesbian, and bisexual training competencies in American Psychological Association accredited graduate programs. Psychotherapy, 42, 116-120.

Shore, E.A. (1996). What Kind of lesbian is a mother. Journal of Feminist Family Therapy, 8(3), 45-62.

Smetana, D.J., \& Bigner, J.J. (2005). Therapeutic experiences of lesbian couples: An exploratory qualitative analysis. Journal of Couple \& Relationship Therapy, 4(1), 23-49.

Solomon, S.E., Rothblum, E.D., \& Balsam, K.F. (2004). Pioneers in partnership: Lesbian and gay male couples in civil unions compared with those not in civil unions and married heterosexual siblings. Journal of Family Psychology, 18(2), 275-286.

Spencer, B., \& Brown, J. (2007). Fusion of internalized homophobia? A pilot study of bowen's differentiation of self hypothesis with lesbian couples. Family Process, 46(2), 257-268.

Speziale, B., \& Ring, C. (2006). Intimate violence among lesbian couples: Emerging data and critical needs. Journal of Feminist Family Therapy, 18, 85-96.

Spitalnick, J.S., \& McNair, L.D. (2005). Couples therapy with gay and lesbian clients: An analysis of important clinical issues. Journal of Sex \& Marital Therapy, 31, 43-56. 
Tanner, L.R., \& Lyness, K.P. (2003). Out of the closet, still in the home: Providing queer affirmative therapy for youth and their families. Journal of Feminist Family Therapy, 15(1), 21-35.

Tasker, F., \& McCann, D. (1999). Affirming patterns of adolescent sexual identity: The challenge. The Association for Family Therapy and Systemic Practice, 21, 30-54.

Thompson, E.A. (2000). Mothers' experiences of an adult child's HIV/AIDS diagnosis: Maternal responses to and resolutions of accountability for AIDS. Family Relations, 49(2), 155-164.

Towbin, M.A., Haddock, S.A., Zimmerman, T.S., Lund, L.K., \& Tanner, L.R. (2003). Images of gender, race, age, and sexual orientation in disney feature-length animated films. Journal of Feminist Family Therapy, 15(4), 19-44.

Treyger, S., Ehlers, N., Zajicek, L., \& Trepper, T. (2008). Helping spouses cope with partners coming out: A solution-focused approach. The American Journal of Family Therapy, 36, 3047.

Tunnell, G., \& Greenan, D.E. (2004). Clinical issues with gay male couples. Journal of Couple \& Relationship Therapy, 3(2/3), 13-26.

Velasquez, M.M., von Sternberg, K., Johnson, D.H., Green, C., Carbonari, J.P., \& Parsons, J.T.(2009). Reducing sexual risk behaviors \& alcohol use among HIV-positive men who have sex with men: a randomized clinical trial. Journal of Consulting \& Clinical Psychology, $77(4), 657-667$.

Vyras, P. (1996). Neglected defender of homosexuality: A commemoration. Journal of Sex \& Marital Therapy, 22(2), 121-129.

Wainright, J.L., \& Patterson, C.J. (2006). Delinquency, victimization, and substance use among adolescents with female same-sex parents. Journal of Family Psychology, 20(3), 526-530. 
Wetchler, J.L. (2004). A Heterosexual therapist's journey toward working with same-sex couples. Journal of Couple \& Relationship Therapy, 3, 137-145.

Wilson, C.M. (2000). The Creation of motherhood: exploring the experiences of lesbian comothers. Journal of Feminist Family Therapy, 12(1), 21-44.

Yarhouse, M.A. (1998). When Clients seek treatment for same-sex attraction: Ethical issues in the "right to choose" debate. Psychotherapy, 35(2), 248-259.

Yarhouse, M.A. (1999). Social cognition research on the formation and maintenance of stereotypes: Application to marriage and family therapists working with homosexual clients. The American Journal of Family Therapy, 27, 149-161.

Yarhouse, M.A. (2001). Sexual identity development: The influence of valuative frameworks on identity synthesis. Psychotherapy, 38, 331-341.

Yarhouse, M.A. (2003). Working with families affected by HIV/AIDS. The American Journal of Family Therapy, 31, 125-137.

Yarhouse, M.A. (2008). Narrative sexual identity therapy. The American Journal of Family Therapy, 36, 196-210.

Yarhouse, M.A., Pawlowski, L.M., \& Tan, E.S.N. (2003). Intact marriages in which one partner dis-identifies with experiences of same-sex attraction. The American Journal of Family Therapy, 31, 375-394.

Yarhouse, M.A., \& Seymore, R.L. (2006). Intact marriages in which one partner dis-identifies with experiences of same-sex attraction: A follow-up study. The American Journal of Family Therapy, 34, 151-161.

Yarhouse, M.A., \& Throckmorton, W. (2002). Ethical issues in attempts to ban reorientation therapies. Psychotherapy: Theory/Research/Practice/Training, 39(1), 66-75. 
Zamarripa, M.X. (1997). A Social constructionist approach for working with ethnic minority gay men and lesbians. Family Therapy, 24(3), 167-176.

Zucker, K.J., \& Spitzer, R.L. (2005). Was the gender identity disorder of childhood diagnosis introduced into DSM-III as a backdoor maneuver to replace homosexuality? A historical note. Journal of Sex \& Marital Therapy, 31, 31-42. 